\title{
Genotoxic and antigenotoxic effects of Fucus vesiculosus extract on cultured human lymphocytes using the chromosome aberration and Comet assays
}

\author{
Cleide Leite-Silva ${ }^{1}$, Cássia Lima Silva Gusmão ${ }^{1}$, Catarina Satie Takahashi ${ }^{1,2}$ \\ ${ }^{1}$ Departamento de Genética, Faculdade de Medicina de Ribeirão Preto, Universidade de São Paulo, \\ Ribeirão Preto, SP, Brazil. \\ ${ }^{2}$ Departamento de Biologia, Faculdade de Filosofia, Ciências e Letras de Ribeirão Preto, \\ Universidade de São Paulo, Ribeirão Preto, SP, Brazil.
}

\begin{abstract}
The brown seaweed Fucus vesiculosus (Fucales, Fucaceae) was screened for its protective activity using doxorubicin-induced DNA damage in human lymphocytes. In this study, we assessed the genotoxic and antigenotoxic potential of three different concentrations $\left(0.25,0.5\right.$ and $\left.1.0 \mathrm{mg} \mathrm{mL}^{-1}\right)$ of $F$. vesiculosus aqueous extract using the chromosome aberration and Comet assays. Treatment of human lymphocyte cultures with $0.25,0.5$ and $1.0 \mathrm{mg} \mathrm{mL}^{-1}$ $F$. vesiculosus aqueous extract had no effect on the chromosome aberration frequency or on the extent of DNA damage detected by the Comet assay. The antigenotoxic effects of the extract were tested in human lymphocyte cultures treated with $15 \mathrm{\mu g} \mathrm{mL}^{-1}$ of doxorubicin, either alone or combined with the different concentrations of the extract, which was added to the cultures before, simultaneously with or after the doxorubicin. Only when lymphocytes were pre-treated with extract there was a reduction in doxorubicin-induced chromosome aberrations and DNA damage as detected by the Comet assay. These results demonstrate that $F$. vesiculosus aqueous extract is not genotoxic in cultured human lymphocytes and indicate that when added to lymphocyte cultures before doxorubicin it has antigenotoxic activity against doxorubicin-induced DNA damage.
\end{abstract}

Key words: antigenotoxicity, chromosomal aberrations, Comet assay, doxorubicin, Fucus vesiculosus.

Received: February 3, 2006; Accepted: May 8, 2006.

\section{Introduction}

Doxorubicin is an anthracycline antibiotic used as an antitumor agent against human malignancies such as leukemia, lymphomas and many solid tumors (Young et al., 1981; Booser and Hortobagyi, 1994) but which also has a wide variety of toxic side-effects, including cardiotoxicity, cytotoxicity and the induction of chromosomal aberrations (Singal et al., 2000; Jung and Reszka, 2001). The reduction of oxidative DNA damage by antioxidants has been evaluated as a chemotherapeutic approach for reducing damage caused by chemotherapy agents such as doxorubicin (Quiles et al., 2002). Alcoholic and aqueous extracts of brown seaweeds have been evaluated for antioxidant activity associated to compounds such as polyphenols and polysaccharides (Jiménez-Escrig et al., 2001; Rupérez et al., 2002). Extracts of the brown seaweed Fucus vesiculosus (Fucales,

Send correspondence to Cleide Leite-Silva. Departamento de Genética, Faculdade de Medicina de Ribeirão Preto, Universidade de São Paulo, Bloco G, Avenida Bandeirantes 3900, Monte Alegre, 14049-900 Ribeirão Preto, SP, Brasil. Email: cleideleite@yahoo. com.br.
Fucaceae) has demonstrated a strong antioxidant activity by the ferric reducing antioxidant power (FRAP) assay (Rupérez et al., 2002).

The alkaline Comet assay is a very useful method for studying genotoxicity in cells exposed in vitro or in vivo to a variety of physical and chemical agents (Tice et al., 2000). It provides a straightforward visual method for assessing DNA damage quantitatively in single cells and is established as a valuable tool in fundamental DNA damage and repair studies (Visvardis et al., 2000). The chromosome aberration assay is also a powerful classical cytogenetic tool for genotoxicity testing and can be used as a validation test for Comet assay results (Hartmann et al., 2003).

We assessed the genotoxic and antigenotoxic potential of $F$. vesiculosus aqueous extract in cultured human lymphocytes. Genotoxicity was measured by the frequencies of chromosome aberrations and the induction of DNA damage as detected by the Comet assay. The antigenotoxic activity of $F$. vesiculosus aqueous extract was evaluated by determining the protective effect of the extract on the fre- 
quency of chromosome aberrations and Comet assay DNA damage induced by doxorubicin.

\section{Material and Methods}

\section{Preparation of Fucus vesiculosus aqueous extract}

A powdered extract of Fucus vesiculosus was kindly donated by Bionatus Botanical Laboratory (São José do Rio Preto, SP, Brazil) and doxorubicin (Eurofarma, São Paulo, Brazil) was kindly provided by the Chemotherapy Center of the University Hospital of Ribeirão Preto-SP, Brazil.

An aqueous suspension of $F$. vesiculosus was prepared by adding $10 \mathrm{~mL}$ of $75^{\circ} \mathrm{C}$ deionized distilled water to $0.5 \mathrm{~g}$ of $F$. vesiculosus powder and agitating the suspension for $1 \mathrm{~h}$ before filtering first through filter paper and then through a $0.22 \mu \mathrm{m}$ Millipore ${ }^{\circledR}$ bacteriological membrane (Millipore ${ }^{\circledR}$, São Paulo, Brazil). The $F$. vesiculosus aqueous extract was used immediately after preparation by adding it to the cell culture medium (see below) to produce final concentrations of $0.25,0.5$ and $1 \mathrm{mg} \mathrm{mL}^{-1}$, with respect to the original $F$. vesiculosus powder, these concentrations being chosen on the basis of preliminary screening trials (data not published).

\section{Lymphocyte cells and culture conditions}

This study was approved by the Research and Ethics Committee of the University Hospital of Ribeirão Preto, São Paulo State (Process HCRP n. 3254/2003) and by the National Comission of Ethics in Research (CONEP; Process $\mathrm{n}^{\circ}$ 2500.084027/2003-29). Peripheral blood samples were collected by venipuncture from 12 healthy, non-smoking, non-alcoholic female volunteers aged 18 to 40 years who had not taken any medicine recently.

Lymphocytes isolated from the blood samples were incubated at $37^{\circ} \mathrm{C}$ in $5 \mathrm{~mL}$ of complete medium consisting of $78 \%$ (v/v) RPMI culture medium (Sigma, St. Louis, MO) $20 \%(\mathrm{v} / \mathrm{v})$ fetal calf serum (Cultilab, Campinas, Brazil) and $2 \%$ (v/v) phytohemagglutinin (Gibco, Carlsbad, CA) supplemented with $0.001 \mathrm{mg} \mathrm{mL}^{-1}$ streptomycin and $0.005 \mathrm{mg}$ $\mathrm{mL}^{-1}$ penicillin.

To determine the antigenotoxicity of $F$. vesiculosus aqueous extract at $0.25,0.5$ or $1 \mathrm{mg} \mathrm{mL}^{-1}$ of culture medium the lymphocyte cultures were submitted to the following treatments: pre-treatment, this consisted of adding the extract $22 \mathrm{~h}$ after starting the incubation of the cultures and $2 \mathrm{~h}$ before addition of doxorubicin; simultaneous-treatment, in which the extract and doxorubicin were added $24 \mathrm{~h}$ after the start of incubation; and post-treatment, in which the extract was added $26 \mathrm{~h}$ after the start of incubation and $2 \mathrm{~h}$ after the addition of doxorubicin, which was added $24 \mathrm{~h}$ after the start of incubation. In all cases the final doxorubicin concentration was $0.15 \mu \mathrm{g} \mathrm{mL}^{-1}$ and all concentrations of extract were tested. Negative control cultures received neither $F$. vesiculosus aqueous extract nor doxorubicin while the positive control cultures received $0.15 \mu \mathrm{g} \mathrm{mL} L^{-1}$ of doxorubicin only. The genotoxicity of $F$. vesiculosus aqueous extract was also investigated by adding the extracts at final concentrations of $0.25,0.5$ or $1 \mathrm{mg} \mathrm{mL}^{-1}$ to the lymphocyte cultures $24 \mathrm{~h}$ after the start of incubation.

The Comet assay was performed $48 \mathrm{~h}$ after the start of incubation. To detect chromosomal aberrations cytological preparations were made $50 \mathrm{~h}$ after the start of incubation because treatment of mammalian cells in vitro with doxorubicin arrests the G2/M phase and delays the cell cycle (O'Loughlin et al., 2000) with $0.016 \% \mathrm{w} / \mathrm{v}$ colchicine (Sigma $12.5 \mu \mathrm{L}$ in $5 \mathrm{~mL}$ ) being added to the cultures $90 \mathrm{~min}$ before harvesting. The cytological preparations were examined by bright-field optical microscopy to asses the mitotic index (MI) and structural or numerical aberrations. Cell viability was determined by the Trypan blue exclusion technique of Pool Zobel et al. (1994) and ranged from 92 to $96 \%$.

\section{Chromosomal aberration assay}

This assay was performed in agreement with current OECD (Organization for Economic Co-operation and Development) and ICH (International Conference on Harmonization) guidelines. After $50 \mathrm{~h}$ incubation each culture was centrifuged at $200 \mathrm{xg}$ for $5 \mathrm{~min}$, after which the supernatant was carefully removed and the pelleted cells resuspended in $5 \mathrm{~mL}$ of hypotonic $0.075 \mathrm{M}$ aqueous $\mathrm{KCl}$ at $37^{\circ} \mathrm{C}$ and then re-pelleted by centrifugeation for a further $5 \mathrm{~min}$ at $200 \mathrm{x}$ g, the supernatant being subsequently removed and the pelleted cells fixed by the addition of $5 \mathrm{~mL}$ of freshlyprepared 3:1 (v/v) methanol:glacial acetic acid. The fixed cells were resuspended and centrifuged for at least three times until the supernatant was clear, after which the cells were re-pelleted and then resuspended in a minimal amount of fresh fixative to obtain an homogeneous suspension. The cell suspension was dropped onto microscope slides and left to air-dry and then stained with 3\% (w/v) Giemsa in a phosphate buffer.

For each treatment and each blood sample (i.e. each individual) the frequency of chromosomal abnormalities were estimated in 100-metaphase plates. The mitotic index (MI) was obtained for each treatment and each blood sample (i.e. each individual) by counting the number of mitotic cells in 2000 cells. The chromosomal aberration types were classified according to Savage's classification (Savage, 1976).

\section{Comet assay}

The Comet assay was performed in its alkaline version following well-established protocols (Singh et al., 1988; Tice et al., 2000). In short, cells from $300 \mu \mathrm{L}$ of each blood sample culture were pelleted by centrifugation. The pellet was added to $160 \mu \mathrm{L}$ of $0.5 \%$ (w/v) low melting point agarose and the mixture spread onto two microscope slides (Knittel, Germany) pre-coated with $1.5 \%$ (w/v) normal 
melting point agarose (Gibco, Carlsbad, CA). The slides were covered with coverslips and were refrigerated for 10 min to solidify the agarose. Next, the coverslips were removed and the slides were immersed in lysis solution (2.5 M NaCl, $100 \mathrm{mM}$ EDTA, $10 \mathrm{mM}$ Tris-HCl (pH 10) plus $10 \%(\mathrm{v} / \mathrm{v})$ dimethyl-sulfoxide and $1 \%(\mathrm{v} / \mathrm{v})$ Triton $\mathrm{X}-100$ ) for at least $60 \mathrm{~min}$ at $4{ }^{\circ} \mathrm{C}$. Subsequently, the slides were placed in an alkaline buffer $(1 \mathrm{mM}$ EDTA $300 \mathrm{mM}$ $\mathrm{NaOH}, \mathrm{pH}>13$ ) for $20 \mathrm{~min}$ at $4{ }^{\circ} \mathrm{C}$ for the DNA to unwind. Following electrophoresis in the same buffer for $20 \mathrm{~min}$ at $300 \mathrm{~mA}$ and $25 \mathrm{~V}\left(0.722 \mathrm{~V} \mathrm{~cm}^{-1}\right)$, the slides were neutralized in $400 \mathrm{mM}$ Tris- $\mathrm{HCl}$ ( $\mathrm{pH} \mathrm{7.5)} \mathrm{for} 15 \mathrm{~min}$, dried at room temperature and fixed in $100 \%$ ethanol for $5 \mathrm{~min}$. The slides were stained with $60 \mu \mathrm{L}$ of $20 \mu \mathrm{g} \mathrm{mL}^{-1}$ aqueous ethidium bromide and covered with coverslips. One hundred randomly selected cells from each sample were analyzed using an epifluorescence microscope (ZEISS Axiolab HB050; $516-560 \mathrm{~nm}$ excitation filter; $590 \mathrm{~nm}$ barrier filter). Images were recorded using an intensified video camera (Axiocam: PCO, Germany). All the steps of the Comet assay were conducted under subdued light. In order to quantify the extent of DNA damage, each cell was visually allocated to one of four classes according to tail size $(0=$ no tail; $1=$ short tail with a length smaller than the diameter of the head (nucleus); 2 = tail length between 1 and 2 times the diameter of the head; and 3 = long tail, more than twice the diameter of the head). Comets with no head and those with almost all the DNA in the tail, or with a very wide tail, were excluded from the analysis, since they could represent dead cells (Hartmann and Speit, 1997). A DNA damage-score was obtained for each sample by multiplying the number of cells in each class by the damage class, according to the formula: Total score $=(0 \times n 0)+(1 \times n 1)+(2 \times n 2)+(3 \times n 3)$, where $\mathrm{n}=$ number of cells in each class. Thus, the total score could range from 0 to 300 .

\section{Statistical analysis}

All results were expressed as mean values \pm the standard deviation $(\mathrm{SD})$ and analyzed with SigmaStat software. Analysis of variance (ANOVA) and the Student-NewmanKeuls test were used to assess significant differences $(\mathrm{p}<0.05)$ between fractions. Gaps were counted, but not included, in the statistical analysis, since their cytogenetic significance is not well established (Antunes and Takahashi, 1998).

\section{Results}

The results of the genotoxicity tests of the $F$. vesiculosus aqueous extracts was assessed in cultured human lymphocytes using the chromosome aberration assay and changes in the mitotic index (MI) are shown in Table 1 and the Comet assay results are shown in Table 2. The fre-

Table 1 - Mitotic index and chromosomal aberrations in human lymphocytes from 12 women treated with Fucus vesiculosus aqueous extract (FVAE) and/or $15 \mu \mathrm{g} \mathrm{mL}^{-1}$ of doxorubicin.

\begin{tabular}{|c|c|c|c|c|c|c|c|c|c|}
\hline \multirow[t]{2}{*}{ Treatment } & \multirow[t]{2}{*}{ Mitotic index $(\%) \pm \mathrm{SD}$} & \multicolumn{6}{|c|}{ Chromosomal aberrations } & \multirow{2}{*}{$\begin{array}{c}\mathrm{TA} / 100 \\
\text { cells }\end{array}$} & \multirow{2}{*}{$\begin{array}{c}\mathrm{AM} / 100 \\
\text { cells }\end{array}$} \\
\hline & & G' & G” & B' & B” & Qr & Sf & & \\
\hline Control group & $6.11 \pm 0.687$ & 35 & 14 & 28 & 12 & 0 & 0 & 3.33 & 3.33 \\
\hline Doxorubicin group & $2.52 \pm 0.397$ & 314 & 288 & 244 & 80 & 16 & 0 & 28.33 & 20.00 \\
\hline \multicolumn{10}{|l|}{ FVAE group $\left(\mathrm{mg} \mathrm{mL}^{-1}\right)$} \\
\hline 0.25 & $5.68 \pm 0.449$ & 34 & 10 & 33 & 9 & 0 & 2 & 3.66 & $3.43^{*}$ \\
\hline 0.5 & $5.77 \pm 0.496$ & 38 & 6 & 33 & 8 & 0 & 2 & 3.58 & $3.54 *$ \\
\hline 1.0 & $5.90 \pm 0.461$ & 44 & 22 & 33 & 10 & 0 & 0 & 3.58 & $3.58^{*}$ \\
\hline \multicolumn{10}{|l|}{ Pre-treatment with FVAE } \\
\hline $0.25 \mathrm{mg} \mathrm{mL}^{-1} \mathrm{FVAE}+$ doxorubicin & $5.90 \pm 0.567$ & 45 & 15 & 31 & 10 & 0 & 0 & 3.41 & $3.37^{*}$ \\
\hline $0.5 \mathrm{mg} \mathrm{mL}^{-1} \mathrm{FVAE}+$ doxorubicin & $5.65 \pm 0.647$ & 55 & 11 & 29 & 13 & 0 & 0 & 3.50 & $3.40^{*}$ \\
\hline $1.0 \mathrm{mg} \mathrm{mL}^{-1} \mathrm{FVAE}+$ doxorubicin & $5.68 \pm 0.551$ & 31 & 13 & 31 & 14 & 0 & 0 & 3.75 & $3.35^{*}$ \\
\hline \multicolumn{10}{|l|}{ Simultaneous-treatment with FVAE } \\
\hline $0.25 \mathrm{mg} \mathrm{mL}^{-1} \mathrm{FVAE}+$ doxorubicin & $2.54 \pm 0.250$ & 335 & 238 & 228 & 45 & 0 & 0 & 22.75 & 19.33 \\
\hline $0.5 \mathrm{mg} \mathrm{mL}^{-1} \mathrm{FVAE}+$ doxorubicin & $2.89 \pm 0.687$ & 339 & 299 & 245 & 37 & 0 & 0 & 23.5 & 19.35 \\
\hline $1.0 \mathrm{mg} \mathrm{mL}^{-1} \mathrm{FVAE}+$ doxorubicin & $3.13 \pm 0.446$ & 353 & 280 & 253 & 21 & 0 & 0 & 22.83 & 19.36 \\
\hline \multicolumn{10}{|l|}{ Post-treatment with FVAE } \\
\hline Doxorubicin $+0.25 \mathrm{mg} \mathrm{mL}^{-1} \mathrm{FVAE}$ & $3.07 \pm 0.431$ & 359 & 290 & 242 & 40 & 5 & 1 & 24.00 & 19.50 \\
\hline Doxorubicin $+0.5 \mathrm{mg} \mathrm{mL}^{-1} \mathrm{FVAE}$ & $3.01 \pm 0.434$ & 343 & 280 & 250 & 34 & 7 & 1 & 24.33 & 19.33 \\
\hline Doxorubicin $+1.0 \mathrm{mg} \mathrm{mL}^{-1} \mathrm{FVAE}$ & $2.91 \pm 0.434$ & 353 & 200 & 262 & 22 & 9 & 1 & 24.5 & 19.66 \\
\hline
\end{tabular}

Key: G' = chromatid gap; G" = chromosomal gap; B' = chromatid break; B" = chromosomal break; Qr = quadriradial; Sf = simple fragment; TA = total aberrations; and $\mathrm{AM}=$ abnormal metaphases. Gaps were not included in the number of abnormal metaphases.A total of 2000 cells per culture were analyzed for mitotic index and 100 cells per culture (1200 cells per treatment) for chromosomal aberrations.

* Significantly different from the doxorubicin group $(\mathrm{p}<0.05)$. 
Table 2 - Comet assay scores for lymphocytes of 12 women treated with three different concentrations of Fucus vesiculosus aqueous extract (FVAE) and/or $15 \mu \mathrm{g} \mathrm{mL}^{-1}$ of doxorubicin. For each treatment 100 nuclei were scored $(\mathrm{n}=1200$ cell/treatment).

\begin{tabular}{|c|c|c|c|c|c|}
\hline \multirow[t]{2}{*}{ Treatments } & \multicolumn{4}{|c|}{ Number of cells with Comet class } & \multirow[t]{2}{*}{ Mean score } \\
\hline & 0 & 1 & 2 & 3 & \\
\hline Control group & 880 & 227 & 31 & 12 & 27.08 \\
\hline Doxorubicin group & 189 & 694 & 236 & 81 & 117.41 \\
\hline \multicolumn{6}{|l|}{ FVAE group $\left(\mathrm{mg} \mathrm{mL}^{-1}\right)$} \\
\hline 0.25 & 872 & 291 & 25 & 12 & $31.41 *$ \\
\hline 0.5 & 884 & 285 & 16 & 15 & $30.16^{*}$ \\
\hline 1.0 & 883 & 282 & 21 & 14 & $30.5^{*}$ \\
\hline \multicolumn{6}{|l|}{ Pre-treatment with FVAE } \\
\hline $0.25 \mathrm{mg} \mathrm{mL}^{-1} \mathrm{FVAE}+$ doxorubicin & 880 & 281 & 26 & 13 & $31 *$ \\
\hline $0.5 \mathrm{mg} \mathrm{mL}^{-1} \mathrm{FVAE}+$ doxorubicin & 875 & 287 & 25 & 13 & $31.33 *$ \\
\hline $1.0 \mathrm{mg} \mathrm{mL}^{-1} \mathrm{FVAE}+$ doxorubicin & 883 & 276 & 27 & 14 & $31^{*}$ \\
\hline \multicolumn{6}{|l|}{ Simultaneous-treatment } \\
\hline $0.25 \mathrm{mg} \mathrm{mL}^{-1} \mathrm{FVAE}+$ doxorubicin & 410 & 490 & 250 & 50 & 95.0 \\
\hline $0.5 \mathrm{mg} \mathrm{mL}^{-1} \mathrm{FVAE}+$ doxorubicin & 359 & 570 & 232 & 39 & 95.92 \\
\hline $1.0 \mathrm{mg} \mathrm{mL}^{-1} \mathrm{FVAE}+$ doxorubicin & 350 & 574 & 245 & 31 & 96.42 \\
\hline \multicolumn{6}{|l|}{ Post-treatment } \\
\hline Doxorubicin DXR $+0.25 \mathrm{mg} \mathrm{mL}^{-1} \mathrm{FVAE}$ & 334 & 567 & 247 & 52 & 101.42 \\
\hline Doxorubicin DXR $+0.5 \mathrm{mg} \mathrm{mL}^{-1} \mathrm{FVAE}$ & 298 & 603 & 252 & 47 & 104 \\
\hline Doxorubicin DXR $+1.0 \mathrm{mg} \mathrm{mL}^{-1} \mathrm{FVAE}$ & 291 & 607 & 261 & 41 & 104.3 \\
\hline
\end{tabular}

* Significantly different from doxorubicin group $(\mathrm{p}<0.05)$.

quency of chromosome aberrations, the mitotic index and the extent of DNA damage in cells treated with different concentrations of the extract were similar to those of the control ( $p>0.05)$, with the most frequent type of chromosome aberration being chromatid and chromosomal gaps (Table 1). In the Comet assay, the most frequent classes were 0 and 1 (Table 2).

The results for the antigenotoxicity assays conducted using doxorubicin in combination with different concentrations of $F$. vesiculosus aqueous extract are also presented in Table 1 for chromosome aberrations and mitotic index and Table 2 for the Comet assay as a measure of DNA damage. No significant difference was found in the chromosome aberration frequency, mitotic index or damage score (i.e. Comet assay results) of cultures submitted to simultaneous and post-treatment with the extract when compared to the doxorubicin group (Table 1 and 2). However, for all the cultures pre-treated with extract the mean mitotic index, chromosome aberration frequency and DNA damage score were all significantly lower than the corresponding values for the doxorubicin group $(\mathrm{p}<0.05)$ (Tables 1 and 2).

The most common chromosome aberrations observed in all cultures treated with doxorubicin were chromatid and chromosomal gaps, followed by chromatid and chromosomal breaks, although quadriradial figures and acentric fragments were also found (Table 1 and Figure 1). In addi- tion, Comet assay cells with class 1 (low-level) damage were the most frequent (Table 2).

\section{Discussion}

Genotoxicity studies have frequently been conducted on mammalian systems to evaluate the mutagenic potential associated with acute or chronic exposure to chemical agents. Recently, particular attention has been devoted to the Comet assay in order to identify substances with genotoxic activity. This test allows the detection of DNA damage such as single and double-strand breaks and alkali labile lesions in individual cells after acute and/or chronic exposure to a genotoxic agent (Tice et al., 2000). According to Hartmann et al. (2003) the chromosome aberration assay can be used to validate the results of the Comet assay.

Our results show that $F$. vesiculosus aqueous extract had no genotoxic effects on human lymphocyte cultures, suggesting that substances present in the extract are not clastogenic nor do they promote DNA damage. Few studies have investigated the toxic effects of this brown seaweed, but according to Oliveira et al.(2003) F. vesiculosus extract could generate reactive oxygen species (ROS), which can damage DNA (Gewirtz, 1999). In contrast, other authors have associated the compounds in this seaweed to antioxidant activity (Jiménez-Escrig, 2001; Rupérez et al., 2002). 

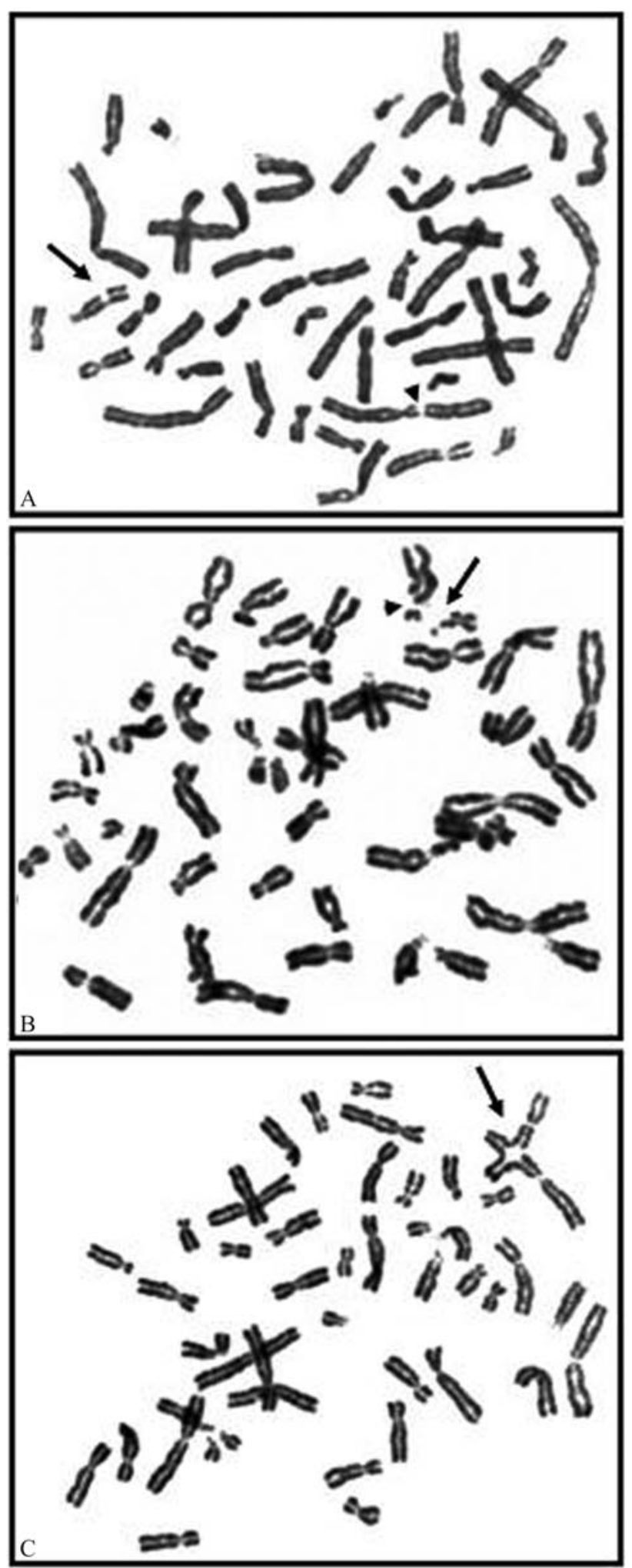

Figure 1 - Chromosomal aberrations observed in cultured human lymphocytes treated with doxorubicin only or doxorubicin plus Fucus vesiculosus aqueous extract using different experimental protocols (pretreatment, simultaneous-treatment and post-treatment). Arrows indicate chromatid gap (A), chromatid break (B) and quadrirradial figure (C). Arrowheads indicate chromosomal gap (A) and chromosomal break (B).
Genotoxic chemotherapy treatments include: alkylating agent that modify DNA bases and thus interfere with DNA replication and transcription; intercalating agents that wedge into the spaces between the nucleotides in the DNA double helix and interfere with transcription and replication; and enzyme inhibitors which induce DNA damage by inhibiting key enzymes such as the topoisomerases which are involved in DNA replication (Jung and Reszka, 2001). According to Gewirtz (1999) doxorubicin is believed to be involved in induction of DNA damage through the inhibition of topoisomerase II and free radical generation by redox reactions.

We found that doxorubicin induced a significant increase $(\mathrm{p}<0.05)$ in DNA damage score and the frequency of chromosome abnormalities, these results being consistent with those reported by other authors (Anderson et al., 1998). In addition, we also found that doxorubicin induced a significant decrease $(\mathrm{p}<0.05)$ in mitotic index, which can be associated with apoptosis. In fact, according to Ling et al. (1996) doxorubicin could induce apoptosis by promoting cyclin B accumulation.

Natural antioxidants have been used to prevent chromosome damage induced by antitumor-agents as a strategy to attenuate the toxicity of chemotherapy with agents such as doxorubicin (Antunes and Takahashi, 1998; Quiles et al., 2002). Algal extracts have demonstrated antioxidative and antitumoral activities on mammals (Funahashi et al., 1999; Rupérez et al., 2002) and for edible brown algae, antioxidant and antimutagenic properties having been identified in alcoholic extracts (Le Tutour et al., 1998) of Laminaria digitata, Himanthalia elongata, Fucus serratus and hot-water-soluble extracts of Laminaria japonica (Okai et al., 1993) and Hijikia fusiforme (Okai and Higashi-Okai, 1994).

Our results show a protective effect of $F$. vesiculosus aqueous extract (FVAE) on pre-treated lymphocyte cultures, although simultaneous or post-treatment of lymphocyte cultures with extract in combination with doxorubicin appeared to result in no protection against the doxorubicin genotoxicity.

Other extracts of brown algae such as Ascophyllum nodosum and Sargassum micracanthum have been shown to produce in vitro protective effects (Le Tutour et al., 1998; Mori et al., 2003) and anti-tumor activity has been observed in mice pre-treated with Undaria pinnatifida extract (Ohigashi et al., 1992).

Antioxidants can be classified into two groups, primary, or chain-breaking, antioxidants and secondary, or preventive, antioxidants (Frei, 1994). In our study, pretreatment of lymphocyte cultures with $F$. vesiculosus aqueous extracts resulted in strong protection against doxorubicin-induced DNA damage, while the extracts themselves produced no significant increase in chromosome aberrations or mitotic index. This suggests that $F$. 
vesiculosus aqueous extracts act as a preventive antioxidant only.

Although many studies highlight the protective activity of seaweeds, there are controversies about the compounds responsible for this activity (Matsukawa et al., 1997; Funahashi et al., 1999; Lim et al., 2002; Ponce et al., 2003). According to Rupérez et al. (2002) the antioxidant activity of the $F$. vesiculosus aqueous extract is due to the sulfated-polysaccharide fucoidan. In brown seaweeds, soluble dietary fiber polysaccharides are mainly represented by alginates, fucans and laminarans and the insoluble fibers are essentially made of cellulose (Bobin-Dubigeon et al., 1997). Sulfated polysaccharides (especially fucans and alginic acid derivatives) of soluble fibers from marine algae are atoxic for humans and, moreover, are known for exhibiting various biological properties, such as anticoagulant, anti-inflammatory, antiviral or antitumoral activities. However, the antioxidant activity of aqueous Fucus extracts has also been associated to its high polyphenolic content (Jiménez-Escrig et al., 2001) and it has been suggested that dietary phytochemical polyphenols prevent oxidative damage in important biological membranes (Decker, 1995). Many algal species also contain polyphloroglucinol phenolics (phlorotannins) (Nakamura et al., 1996) and in several cases, the antioxidant activity of algae could be due to these compounds. Other authors have associated the protective effect of seaweeds to their iodine content. For example, Funahashi et al. (1999) have suggested that the iodine contained in edible seaweed have suppressive effects on mammary tumor cells. According Moro and Basile (2000) iodine is the most important active principle in $F$. vesiculosus, although its constituents also include polysaccharides, sterols and other minerals. Iodine is known to play an important role in the treatment of obesity and thyroid disorders and iodine deficiency has also been associated with the development of mammary pathology and cancer (Venturi, 2001).

Our results demonstrate that Fucus vesiculosus aqueous extracts have no genotoxic effect on lymphocyte cultures and can provide effective protection to lymphocytes against doxorubicin-induced DNA damage, but only when administered before doxorubicin. Our findings indicate that further investigations are necessary to evaluate the in vivo benefits of Fucus vesiculosus aqueous extract. Moreover, the evaluation of other seaweed extracts using the model described in this paper may also contribute to the discovery of new marine resources able to protect DNA against the undesirable effects of antitumor agents.

\section{Acknowledgments}

The authors thank the women who spontaneously participated in this study and Sílvio A. dos Santos, Raquel A. dos Santos, Ana Paula L. Montaldi and Luiz A. da Costa Junior for technical assistance. This research was supported by grants from the Brazilian agencies Coordenação de
Aperfeiçoamento de Pessoal de Nível Superior (CAPES) and Fundação de Apoio ao Ensino, Pesquisa e Assistência (FAEPA).

\section{References}

Anderson D, Yu T-W and McGregor DB (1998) Comet assay responses as indicators of carcinogenic exposure. Mutagen 13:539-555.

Antunes LM and Takahashi CS (1998) Effects of high doses of vitamins $\mathrm{C}$ and $\mathrm{E}$ against doxorubicin-induced chromosomal damage in Wistar rat bone marrow cells. Mutat Res 419:137-143.

Bobin-Dubigeon C, Hoebler C, Lognoné V, Dagorn-Scaviner C, Mabeau S, Barry J-L and Lahaye M (1997) Chemical composition, physicochemical properties, enzymatic inhibition and fermentative characteristics of dietary fibers from edible seaweeds. Sci Aliments 17:619-639.

Booser DJ and Hortobagyi GN (1994) Anthracycline antibiotics in cancer therapy: Focus on drug resistance. Drugs 47:223258.

Decker E (1995) The role of phenolics, conjugated linoleic acid, carnosine, and pyroquinoline quinone as nonessential dietary antioxidants. Nutr Rev 53:49-58.

Frei B (1994) Antioxidative in Human Health and Disease. Academic Press, San Diego, 62 pp.

Funahashi H, Imai T, Tanaka Y, Tsukamura K, Hayakawa Y, Kikumori T, Mase T, Itoh T, Nishikawa M, Hayashi H, Shibata A, Hibi Y, Takahashi M and Narita T (1999) Wakame seaweed suppress the proliferation of 7, 12- dimethylbenz $(a)$ - anthracene-induced mammary tumors in rats. Jpn J Cancer Res 90:922-927.

Gewirtz DA (1999) A critical evaluation of the mechanisms of action proposed for the antitumor effects of the antracycline antibiotics adriamycin and daunorubicin. Biochem Pharmacol 57:727-741.

Hartmann A and Speit G (1997) The contribution of cytotoxicity to DNA effects in the single cell gel test (Comet assay). Toxicol Lett 10:183-188.

Hartmann A, Plappert U, Poetter F and Suter W (2003) Comparative study with the alkaline Comet assay and the chromosome aberration test. Mutat Res 536:27-38.

Jiménez-Escrig A, Jiménez-Jiménez I, Pulido R and Saura-Calixto F (2001) Antioxidant activity of fresh and processed edible seaweeds. J Sci Food Agric 81:530-534.

Jung K and Reszka R (2001) Mitochondria as subcellular targets for clinically useful anthracyclines. Adv Drug Deliv Rev 49:87-105.

Le Tutour B, Benslimane F, Gouleau MP, Gouygou JP, Saadan B and Quemeneur F (1998) Antioxidant and pro-oxidant activities of the brown algae, Laminaria digitata, Himanthalia elongata, Fucus vesiculosus, Fucus serratus and Ascophyllum nodosum. J Appl Phycol 10:121-129.

Lim SN, Cheung PCK, Ooi VEC and Ang PO (2002) Evaluation of antioxidative activity of extracts from a brown seaweed, Sargassum siliquastrum. J Agric Food Chem 50:3862-3866.

Ling YH, El-Naggar AK, Priebe W and Perez-Soler R (1996) Cell cycle-dependent cytotoxicity, G2/M phase arrest, and disruption of $\mathrm{p} 34 \mathrm{cdc} 2 /$ cyclin $\mathrm{B} 1$ activity induced by doxorubicin in Synchronized P388 cells. Mol Pharmacol 49:832-841. 
Matsukawa R, Dubinsky Z, Kishimoto E, Masaki K, Masuda Y, Takeuchi T, Chihara M, Yamamoto Y, Niki E and Karube I (1997) A comparison of screening methods for antioxidant activity in seaweeds. J Appl Phycol 9:29-35.

Mori J, Matsunaga T, Takahashi S, Hasegawa C and Saito H (2003) Inhibitory activity on lipid peroxidation of extracts from marine brown alga. Phytotherapy Res 17:549-551.

Moro CO and Basile G (2000) Obesity and medicinal plants. Fitoterapia 71:573-582.

Nakamura T, Nagayama K, Uchida K and Tanaka R (1996) Antioxidant activity of phlorotannins isolated from the brown alga Eisenia bicyclis. Fish Sci 62:923-926.

Ohigashi H, Sakai Y, Yamaguchi K, Umezaki I and Koshimizu K (1992) Possible anti-tumor promoting properties of marine algae and in vivo activity of wakame seaweed extract. Biosci Biotech Biochem 56:994-995.

Okai Y, Higashi-Okai K and Nakamura S (1993) Identification of heterogenous antimutagenic activities in the extract of edible brown seaweeds, Laminaria japonica (Makonbu) and Undaria pinnatifida (Wakame) by umu gene expression system in Salmonella typhimurium (TA 1535/pSK 1002). Mutat Res 302:63-70.

Okai Y and Higashi-Okai K (1994) Identification of antimutagenic activities in the extract of a brown alga, Hijkia fusiforme (Hijiki) by uти gene expression system in Salmonella typhimurium (TA 1535/pSK 1002). J Sci Food Agric 66:103-109.

Oliveira JF, Oliveira MBN, Ávila AS, Braga ACS, Catanho MTJA, Jales RLC, Cardoso VN and Bernado-Filho M (2003) Assessment of the effect of Fucus vesiculosus extract on the labing of blood constituents with technetium-99m and the histological modifications on the shape of the red blood cells. Food and Chem Toxicol 41:15-20.

O'Loughlin C, Heenan M, Coyle S and Clynes M (2000) Altered cell cycle response of drug-resistant lung carcinoma cells to doxorubicin. Eur J Cancer 36:1149-1160.
Ponce NMA, Pujol CA, Damonte EB, Flores ML and Stortz CA (2003) Fucoidans from the brown seaweed Adenocystis utricularis: Extraction methods, antiviral activity and structural studies. Carbohydr Res 338:153-165.

Pool Zobel BL, Lotzmann N, Knoll M, Kuchenmeister F, Lambertz R, Leucht U, Schroder HG and Schmezer P (1994) Detection of genotoxic effects in human gastric and nasal mucosa cells isolated from biopsy samples. Environ Mol Mutagen 24:23-45.

Quiles JL, Huertas JR, Battino M, Mataix J and Ramírez-Tortosa MC (2002) Antioxidant nutrients and adriamycin toxicity. Toxicology 180:79-95.

Rupérez P, Ahrazem O and Leal JA (2002) Potential antioxidant capacity of sulfated polysaccharides from the edible marine brown seaweed Fucus vesiculosus. J Agric Food Chem 50:840-845.

Savage JR (1976) Classification and relationships of induced chromosomal structural changes. J Med Genet 13:103-122.

Singal PK, Li T, Kumar D, Danelisen I and Iliskovic N (2000) Adriamycin- induced heart failure:mechanism and modulation. Mol and Cell Biochem 207:77-85.

Singh NP, McCoy MT, Tice RR and Schneider EL (1988) A simple technique for quantitation of levels of DNA damage in individual cells. Exp Cell Res 175:184-191.

Tice RR, Agurell E, Anderson D, Burlinson B, Hartmann A, Kobayashi H, Miyamae Y, Rojas E, Ryu J-C and Sasaki YF (2000) Single cell gel/Comet assay: Guidelines for in vitro and in vivo genetic toxicology testing. Environ $\mathrm{Mol} \mathrm{Mu}-$ tagen 35:206-221.

Venturi S (2001) Is there a role for iodine in breast diseases? Breast 10:379-382.

Visvardis EE, Haveles KS, Patarias TA, Margaritis LH, Sophianopoulou V and Sideris EG (2000) Diversity of peripheral blood mononuclear cells as revealed by a novel multiple microgel "Comet assay". Environ Mol Mutagen 36:32-39.

Young RC, Ozols RF and Myers CE (1981) The antharacycline antineoplastic drugs. New Engl J Med 305:139-153. Associate Editor: Carlos F.M. Menck 